\title{
PENDAMPINGAN PENGOLAHAN PANGAN DAN PENGEMASAN PRODUK BAGI PELAKU USAHA MIKRO KECIL DAN MENENGAH (UMKM) BIDANG PANGAN DI KECAMATAN BUA KABUPATEN LUWU
}

\author{
Nurasia $^{1^{*}}$ \\ Rahmat Hidayat ${ }^{2}$ \\ Fitrah Al Anshori ${ }^{3}$ \\ 1,2,3 Universitas Cokroaminoto Palopo, Palopo, Indonesia \\ nurasia.kimia99@gmail.com $^{\left.1^{*}\right)}$ \\ dayatmath@gmail.com ${ }^{2}$ \\ fitrahbiologi@gmail.com ${ }^{3}$
}

Kata Kunci: [Produk,

Pengolahan, Pengemasan,

Masyarakat usaha]

Published by:

\begin{abstract}
Abstrak: Kegiatan Pendampingan Pengolahan Pangan dan Pengemasan Produk bagi Pelaku Usaha Mikro Kecil dan Menengah (UMKM) Bidang Pangan di Kecamatan Bua Kabupaten Luwu bertujuan untuk memberikan pemahaman kepada pelaku UMKM khususnya di bidang pangan terkait pentingnya pengolahan pangan yang baik serta pengemasan produk yang baik sehingga dapat meningkatkan minat konsumen. Kegiatan ini dilaksanakan selama 2 bulan secara luring dan daring. Kegiatan luring berupa pelatihan dan pendampingan pengolahan produk yang memenuhi standar Cara Pengolahan Prodak Pangan yang Baik-Industri Rumah Tangga (CPPB-IRT) berdasarkan standar yang ditemtukan oleh Badan Pengawasan Obat dan Makanan (BPOM). Kegiatan dilanjutkan dengan pelatihan mengenai cara pengemasan prodak yang baik sehingga dapat meningkatkan minta konsumen yang dapat memberikan dampak positif terhadap peningkatan pendapatan bagi pelaku UMKM. Adapun kegiatan daring yang direncanakan berupa pendampingan dan pembinanaan kepada para peserta melalui WA Group. Adapun hasil yang diharapkan dari kegiatan ini adalah berupa kemasan produk pangan dari pelaku UMKM yang siap dipasarkan, serta jurnal pengabdian yang diteribkan di jurnal nasional serta sertifikat HKI.
\end{abstract}

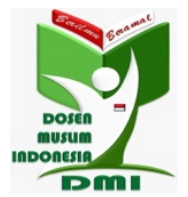

Copyright (C) 2021 The Author(s)

This article is licensed under CC BY 4.0 License (cc) $\mathrm{EY}$

https://dmi-journals.org/jai 


\section{Pendahuluan}

Usaha Mikro Kecil dan Menengah (UMKM) merupakan salah satu jenis usaha yang dilaksnakan baik secara perorangan maupun kelompok dengan skala produksi yang masih kecil dengan memanfaatkan dapur rumah tangga. Di masa pandemic Covid19 Saat ini terjadi peningkatan pelaku usaha mikro khususnya di bidang pangan. Hal ini dikarenakan adanya beberapa aturan pemerintah seperti Pembatasan Sosial Berskala Besar (PSBB) yang berdampak pada keterbatasan mobilitas warga sehingga salah satu pilihan konsumen adalah produk-produk usaha yang di produksi oleh para pelaku UMKM Lokal.

Hasil observasi yang dilakukan oleh Tim pelaksana menunjukkan bahwa Peningkatan pelaku UMKM di bidang pangan tidak sejalan dengan penerapan hygiene dan sanitasi pengolahan produk yang baik. Sehingga, perlu diadakan pendampingan mengenai Cara Pengolahan Produk Pangan yang Baik bagi pelaku Industri Rumah Tangga (CPPB-IRT). Produk yang dihasilkan dari hasil pengolahan pangan yang baik harus didukung dengan kemasan yang baik dan menarik sehingga dapat meningkatakan minat konsumen. Saat ini, pengemasan merupakan salah satu faktor penting dalam persaingan dunia usaha. Hampir semua orang membutuhkan kemasan untuk setiap produknya. Kemasan yang baik tidak hanya berfungsi sebagai pelindung dari kerusakan tetapi juga memiliki nilai estetika yang dapat menarik pelanggan terhadap produk pangan yang dihasilkan. Cara-cara pengemasan dan labeling yang baik dan menarik tentu sangat diperlukan dalam mendukung suatu produk makanan. Sayangnya belum semua produsen seperti Usaha Mikro Kecil dan Menengah (UMKM) dapat menerapkannya.

Sampai saat ini kemasan produk masih merupakan masalah bagi para pengelola usaha, khususnya Usaha Mikro Kecil dan Menengah. Permasalahan tentang kemasan produk dan labelnya kadang-kadang menjadi kendala bagi perkembangan atau kemajuan suatu usaha. Banyak persoalan yang muncul ketika suatu usaha ingin memiliki suatu kemasan produk yang baik, berkualitas dan memenuhi standar nasional yang ada. Persoalan-persoalan yang sering dihadapi seperti bahan pengemas, desain bentuk kemasan, desain label, sampai pada persoalan yang paling utama yaitu biaya pembuatan kemasan itu sendiri. Bagi para pengelola UMKM dengan segala keterbatasan modal usaha sebaiknya permasalahan tentang kemasan bisa ditangani dengan kreativitasnya.

Kemasan yang baik dan menarik tidak selalu identik dengan harga kemasan yang mahal. Dengan bahan pengemas yang biasa-biasa saja, asalkan dirancang sedemikian rupa baik bentuk maupun desain labelnya pastilah akan tercipta sebuah kemasan yang tidak kalah bersaing dengan kemasan-kemasan modern. Produk hasil industri rumah tangga pangan pada umumnya dicirikan dengan suatu gambaran yang kurang baik yaitu diolah dengan tingkat sanitasi dan hygiene yang rendah, menggunakan bahan baku dengan tingkat mutu dan kesegaran yang rendah, keamanan pangannnya tidak terjamin, teknologi yang digunakan secara turun temurun, teknologi pengemasan yang digunakan belum memadai, dan usaha dikelola oleh keluarga dengan tingkat kemampuan manajemen yang kurang memadai (Hariyadi \& Dewanti, 2011). Oleh karena itu perlu pengembangan teknologi pengolahan dengan beberapa upaya perbaikan dengan penerapan dasar proses pengolahan pangan. Aspek manajemen mutu dan keamanan 
bahan baku dan produk perlu dikaji untuk pengembangan usaha dan pengembangan pemasaran produk.

Dalam kegiatan pengemasan dan strategi pemasaran produk pangan, beberapa peneliti telah mengkaji hal tersebut, seperti (Nugroho, 2011); (Sulistyandari, Widiastuti, \& Indriati, 2017) dalam penelitiannya tentang "Kemasan Produk Sebagai Strategi Pemasaran Kerupuk Rambak "Mirasa" di Desa Dukuhturi, Kec. Bumiayu, Kab. Brebes". Hasil kegiatan ini adalah kegiatan produksi yang dilakukan masih tergolong sederhana dan dari aspek pemasaranpun masih sangat sederhana. Produk dikemas dengan cara kuno yaitu hanya menggunakan kemasan plastik yang distaples dan belum menggunakan label serta kardus biasa dengan label fotokopi. Sepanjang kegiatan berjalan, mitra mendapatkan penyuluhan dan pendampingan usaha dari Tim. Mitra juga telah berhasil memperpanjang izin usaha PIRTnya untuk lima tahun ke depan dan telah membuat label merek yang baru yang dapat menambah nilai jual produknya.

Berdasarkan latar belakang yang ada maka tim dosen dari Universitas Cokroaminoto Palopo tertarik untuk melakukan pendampingan terkait pengolahan pangan dan pengemasan pangan yang baik bagi pelaku Usaha Kecil dan Mengah (UMKM) di Kecamatan Bua Kabupaten Luwu.

\section{Metode Pelaksanaan} yakni:

Pelaksanaan kegiatan pengabdian ini secara garis besar terdiri dari 3 tahapan

\section{Tahapan persiapaan}

Tahapan persiapan pada kegiatan pendampingan terkait pengolahan pangan dan pengemasan pangan yang baik bagi pelaku Usaha Kecil dan Mengah (UMKM) di Kecamatan Bua Kabupaten Luwu yaitu mengidentifikasi para pelaku UMKM yang memilki pemahaman tentang pengolahan dan pengemasan produk yang masih rendah. Tahapan ini dilakukan wawancara kepada pelaku UMKM di Kecamatan Bua Kabupaten Luwu khususnya di Bidang pangan. Tahapan persiapan dilakukan dari Bulan Oktober 2021.

\section{Tahapan pelaksanaan}

Tahapan pelaksanaan secara umum dilakukan melakukan tiga kegiatan utama yaitu pelatihan pengolahan pangan dan pengemasan produk yang baik bagi pelaku UMKM di Kecamatan Bua Kabupaten Luwu. Pelaksanaan pelatihan direncanakan secara luring selama 2 hari; yang terdiri dari kegiatan pelatihan pengolahan pangan yang baik pada hari pertama dilanjutkan dengan pengemasan produk pada hasil kedua. Kegiatan kemudian dilanjutkan dengan pendampingan untuk perbaikan kemasan/follow up kegiatan pelatihan selama 4 Pekan. Kegiatan pelaksanaan direncanakan pada bulan November-Desember 2021.

\section{Tahapan Evaluasi}

Tahapan evalusi rencananya akan dilaksanakan setiap 2 pekan dengan melihat perbandingan produktivitas dan pendapatan usaha sebelum dan setalah kegiatan pelatihan pengolahan produk dan kemasan bagi pelaku UMKM. Kegiatan ini dilakukan 
secara daring melalui laporan setiap pekan dan laporan akhir usaha di minggu keempat bulan Desember 2021.

\section{Hasil dan Pembahasan}

Pada Pelaksanaan pengabdian kepada masyarakat berupa kegiatan pendampingan terkait pengolahan pangan dan pengemasan pangan yang baik bagi pelaku Usaha Kecil dan Mengah (UMKM) di Kecamatan Bua Kabupaten Luwu. Pelaku usaha yang menjadi mitra dalam kegiatan ini adalah pelaku UMKM yang terletak di beberapa Desa di Keacamatan Bua Kabupaten Luwu. Para pelaku UMKM ini dikoordinatori oleh IKM Nurhidayah Bua, dimana didalamnya terdapat 30 orang pelaku UMKM yang masih aktif melakukan kegiatan produksi.

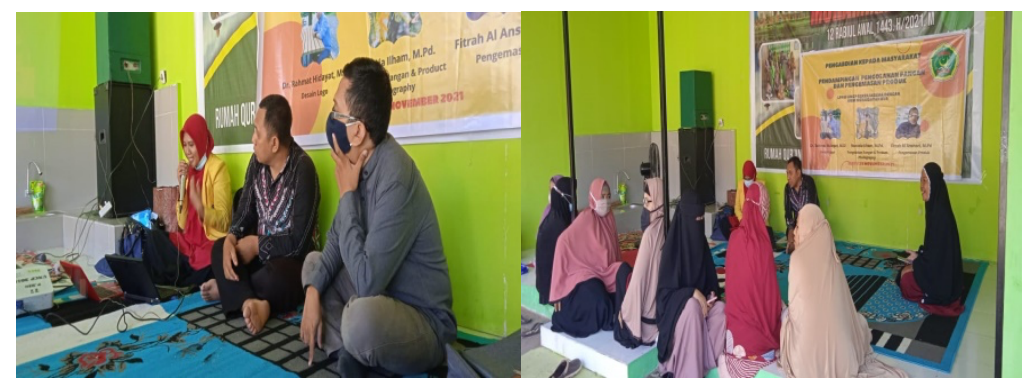

Gambar 1. Pelatihan dan pendampingan pengolahan pangan dan pengemasan produk

Jenis usaha yang di kembangkan oleh pelaku UMKM dalam kegiatan ini berupa usaha yang berbasis pangan. Adapun beberapa jenis pangan yang dihasilkan oleh para pelaku UMKM ini adalah pop corn, tape, aneka olahan sambal, kue kering, kue tradisional, jus patika, manisan pepaya dan lain-lain. Berdasarkan hasil pengamatan yang dilakukan, masih terdapat produk yang belum memiliki logo dan kemasan yang baik. Salah satu produknya yaitu sambal dan manisan pepaya yang di produksi oleh UMKM Kreasi Ummi yang terletak di Desa Karang-Karangan Kecamatan Bua Kabupaten Luwu.

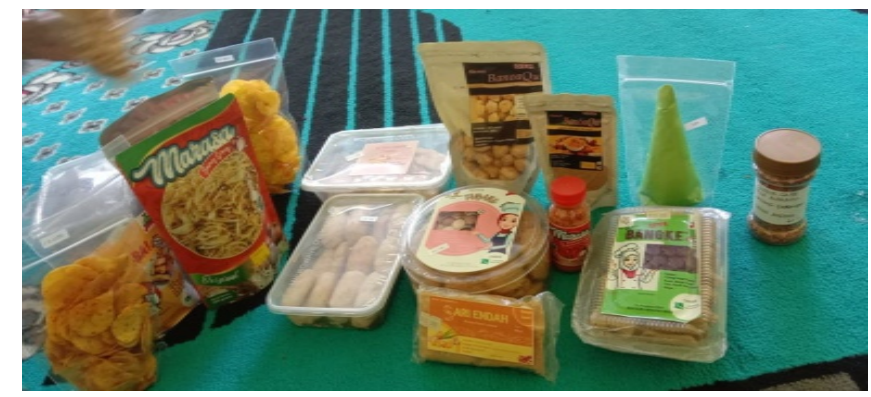

Gambar 2. Jenis produk UMKM Bidang Pangan di Kecamatan Bua

Kegiatan dalam Abdimas ini diawali dengan tahapan persiapan yang terdiri dari observasi dan wawancara dengan para pelaku usaha. Pada tahapan pelaksanaan dilakukan kegiatan berupa pelatihan pengolahan produk pangan yang baik atau Cara Pengolahan Produk Pangan yang Baik bagi pelaku Industri Rumah Tangga (CPPB-IRT) yang mengacu pada aturan yang telah ditetapkan oleh Badan POM dan Dinas Kesehatan. 
Kegiatan ini dilaksanakan selama satu hari yakni pada tanggal 20 November 2021. Dalam kegiatan ini terdapat dua materi utama yakni materi terkait cara pengolahan produk pangan yang baik serta cara memahami kualitas bahan pangan yang digunakan dalam pelaksanaan produksi usaha kecil dan menengah berbasis pangan. Materi kedua adalah cara mengenal jenis kemasan yang sesuai dengan jenis produk yang dihasilkan serta pengemasan produk pangan. Kegiatan ini juga terdapat pelatihan teknik dasar mengenai pengambilan produk pangan pangan yang baik atau praktik Food Photography untuk produk usaha yang dihasilkan agar lebih menarik dan meningkatkan minat konsumen.

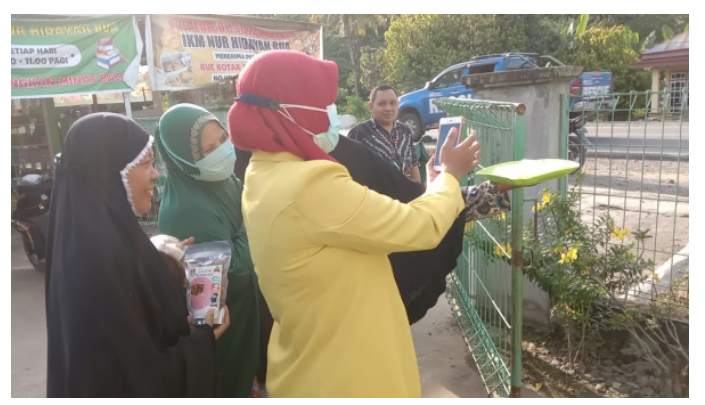

Gambar 3. Praktik Pengambilan Gambar produk UMKM Bidang Pangan di Kecamatan Bua

Kegiatan dilanjutkan dengan pendampingan para pengusaha dalam desain produk dan membantu pelaku usaha dalam pembuatan dan pengadaan logo yang baik untuk kemasan produk pangan yang dihasilkan. Salah satu jenis produk yang di desain logo nya adalah produk sambal dan manisan pepaya yang dihasilkan dari UMKM Kreasi Ummi. Selanjutnya untuuk kegiatan evaluasi berupa analisis terkait kemajuan usaha dengan melihat frekuensi produksi sebelum dan setelah dilaksanaannya pelatihan dan pendampingan pengolahan pangan oleh para pelaku UMKM di Kecamatan Bua Kabupaten Luwu. Kegiatan evaluasi ini dilaksanakan secara daring melalui WA group.

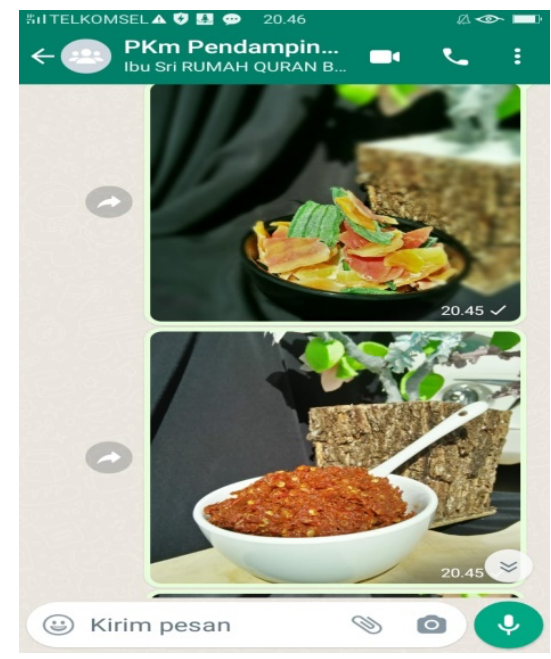

Gambar 4. Pendampingan dan evaluasi secara online

Berdasarkanhasil evaluasi dan wawancara dengan para pelaku usaha yang telah mengikuti pendampingan menyampaikan bahwa setelah mengikuti kegiatan terkait 
pengolahan produk pangan yang baik, pelaku usaha mulai menerapkan prinsip hygen dan sanitasi yang baik utamanya dalam tahapan produksi. Di sisi lain, pembuatan desain logo dan penggunaan kemasan yang baik juga meningkatkan nilai estetika dari produk sehingga dapat menarik minat pembeli. Peningkatan minat dari para konsumen diharapkan dapat berpengaruh positif terhadap hasil penjualan produk dari para pelaku UMKM khususnya para pelaku usaha pangan yang terdapat di Kecamatan Bua.

\section{Kesimpulan}

Berdasarkan evaluasi kegiatan yang dilakukan maka dapat disimpulkan bahwa:

1. Pelaku usaha dan UMKM membutuhkan pendampingan dari pihak terkait baik pemerintah maupun swasta dalam meningkatkan produktivitas usahanya

2. Kegiatan Pendampinagn pengolahn pangan yang baik pelaku usaha UMKM di bidang pangan sangat dipetlukan bagi pelaku usaha agar produk yang dihasilkan memiliki tingkat hiegenitas dan sanitasi yang baik sehingga dapat meningkatkan minat konsumen/pasar.

3. Kegiatan pendampingan pengemasan produk yang baik sangat dibutuhkan bagi pelaku usaha untuk meningkatkan minat konsumen sehingga dapat meningkatkan kesejahteraan para pelaku UMKM.

\section{Ucapan Terimakasih}

Terimakasih yang sebesar-besarnya kami ucapkan kepada seluruh pihak yang telah ikut andil dalam kegiatan ini terkhusus buat LPPM Universitas Cokroaminoto Palopo yang telah memberikan fasilitas dalam pelaksaan kegiatan, para pemateri dan para pelaku Usaha Mikro Kecil dan Menengah atas partisipasinya dalam kegiatan pelatihan dan pendampingan UMKM di kecamatan Bua Kabupaten Luwu.

\section{Referensi}

Bappenas, 2020, strategi pengembangan UMKM, (Online), https://www.bappenas.go.id/id/berita-dan-siaran-pers/bahas-strategipengembangan-umkm-dengan-pengrajin-bambu-bappenas-dorong-pemanfaatanteknologi-digital, diakses pada tanggal 12 Desember 2020.

Undang-Undang Nomor 7 tahun 1996 tentang pangan (online), diakses diakses pada tanggal 12 Desember 2020.

Hariyadi, R., \& Dewanti, R. 2011. Memproduksi Pangan yang Aman. Jakarta: Dian Rakyat.

Nugroho, S. P. 2011. Karakteristik Usaha Kecil di Indonesia Perencanaan Pemasaran Usaha Kecil Rumahan. BENEFIT: Jurnal Manajemen Dan Bisnis, 14(1), 31-40. doi:https://doi.org/10.23917/benefit.v14i1.1316

Sulistyandari, Widiastuti, E., \& Indriati, S. 2017. Kemasan Produk Sebagai Strategi Pemasaran Kerupuk Rambak "Mirasa” di Desa Dukuhturi, Kec. Bumiayu, Kab. Brebes. Adimas : Jurnal Pengabdian Kepada Masyarakat, 1(2), 1. doi:10.24269/adi.v1i2.597 